\title{
THE DERIVATIONAL AFFIXES ANALYSIS OF GAP FILL PARAGRAPH ON UNAS AT SENIOR HIGH SCHOOL
}

\author{
Fatih Al Fauzi \\ fatih.alfauzi@uij.ac.id \\ Pendidikan Bahasa Inggris, Fakultas Keguruan dan Ilmu Pendidikan, \\ Universitas Islam Jember
}

\begin{abstract}
Affixation is the use of adding a morpheme or affix to an already existing word to create a new word to help describe its use in a sentence, and there are two types of affixes Derivational and Inflectional. Affixes can found in the various text, in newspaper, magazine and in media online text act. This research is focus on Derivational Affixes analysis on Gap Fill paragraph at UN (National Examination). Analyzing UN is one way to know the extent to which the quality of the UN that we use in the exam national system that we use in the learning system and also have an important role for the teacher and student learning as a reference and to assist student learning. While the result of the study Derivational affixes in gap fill paragraph on UN (National Examination) are -ly (8), un(1), -ion (1), -ment (1), dis- (1). It shows that have the most frequently appear in gap fill paragraph on UN (National Examination) are suffix $-l y$ as an adverb marker. The word of changing the part of speech that found in gap fill paragraph on UN (National Exam) are : adjective, adverb, noun and verb.
\end{abstract}

Keywords: Derivational Affixes, Gap Fill \& UN

\section{INTRODUCTION}

All of education level has English as crucial subject. English is an obligatory subject for the students. English has been put in curriculum of education as one of an compulsory subject at junior and senior high school, and it is still given in the university. Moreover, English is learned as a school subject for the purpose of giving the students a foreign language competence which he or she may use it for communication. It is provided by English lesson became one of the subject of UN. The National Examination (UN) is one of the goverments's evaluation way, it is another form of EBTANAS (Evaluation of the National Final Stage of Learning) that was previously removed. The UN is an appropriate meansuring instrument to measure the level of achievment of educational goals that have been set. UN is the system used to test the learner's ability to choose A, B, C, D or E and so on, the National Examination is also an attempt by Departement of National Education to determine a perfect students standart. UN is used to form an independent. The function of UN as a "quality control" of educational system, because the control of the process, in-put of education have been smaller.

Nowdays, USBN determine the graduation. Many people do not know that the National Examination (UN) doesn't determine the graduation. If now cann't it, because every the students scores is out. The data of students scores have been locked directly by Basic Education Data. The schools can't falsify the scores now, because a week after UN the scores have to enter. (detik.com 24 Maret 2017)

In this case the writer wants to analyze morphological found in gap fill paragraph on UNAS at senior high school especially in derivational affixes, because morphology is the sciences that discuss the intricacies of form words. There are types of morphology, types of morphemes and types of affixes from all of the types we can know formation of new words and also new meaning from those words. Through the morphological process, we can classify the form of noun, verb, adjective and adverb become new word by putting word together such as "act" as verb become 
"action" as noun, "agree" as verb become "agreement" as noun or "happy" as adjective become "happiness" as noun, etc. Clearly there are many kinds of the marker that make the morphological process in English.

\section{Morphology}

Morphology is the branch of science about word formation. In morphology when wrong to use affixtion, There will be miscommunication or not able to

communicate well. Therefore, understanding the use of affixation is very important. According Lieber (2009:2) stated that morphology is the study of word formation, including the ways new words were coined in the languages of the world, and the way forms of words are varied depending on how they're used in sentences. In addition, Carlisle and Fleming (cited in Varatharajoo et al., 2015:47) assert that morphological knowledge is important for students to understand the meaning from words. Furthermore, according Mountain et al.,2011 (cited in Varatharajoo et al., 2015:48) claim that morphological knowledge help students to examine the morphologically complex word for its meaningful parts to discover the word's meaning.

a. Derivation

Derivation is also constrained by the grammatical category of a base word (Zhang \&, 2013) cited in (Varatharajoo et al., 2015:47). Derivational morpheme is largely limited to phonetically transparent and common froms (e.g., teach-teacher, quiet-quetly). According to Plag (2002:20) states, not all derivational affixes are category-changing, as is evidenced, for example, by most prefixes (as e.g. in post-war, decolonialize, non-issue), or by the nominal suffix - ism, which can attach to nouns to form nouns (e.g. Terrorism). Derivational suffixes can and do occur inside other derivational suffixes. A derivational affix is an affix by means of which one word is formed (derived) from another. The derived word is often of a different word class from the original. In derivation a new word is formed by adding an affix to the root or stem, Derivational morphemes form new words either:

1. By changing the meaning of the base to which they are attached. E.g. kind - unkind (adjectives), obey - disobey (verbs)

2. By changing the word-class that a base belongs to. E.g. kind- kindly, simple - simple

b. Inflectional

According Plag (2002:19) only irregular inflection makes use of nonaffixational means, as for example in mouse - mice or sing - sang. There is no inflectional prefix in English. Furthermore, forms like workers or colonializing indicate that inflectional morphemes always occur outside derivational morphemes, they close the word for further (derivational) affixation (*workers-hood, *colonializing-er). Inflectional morpheme this morpheme can only be a suffix. The $s$ in cats is an inflectional morpheme. An inflectional morpheme creates a change in the function of the word.

\section{Vocabulary}

Vocabulary is primarily associated with the number of words that a person knows; one either has a large or a small vocabulary. The vocabulary may indeed refer to the collection of words known by an individual or by a large group of people. However if we are lack of vocabulary, we will find the difficulties in understanding the meaning of the language. Anyway if we have enough vocabulary it will make us easier to learn a new language and to understand the meaning of the language. According to Thornbury (2002:13) "without grammar very little can be conveyed, without vocabulary nothing can be conveyed". 
Here it is clear that the vocabulary is more important than the grammar, because someone can speak without proper grammar arrangement, but someone can't say something without mastering vocabulary.

\section{UN (National Examination)}

National Examination (UN) is one of the goverments's evaluation way, it is another form of EBTANAS (Evaluation of the national final stage of learning) that was previously removed. The $\mathrm{UN}$ is an appropriate meansuring instrument to measure the level of achievment of educational goals that have been set. In Permen No. 3 year 2017 explain that "UN is activity of meansuring graduate competency achievement on certin subjects nationally with reference to competency standard of graduate.

\section{Gap Fill}

Gap fill is particulary useful in testing reading. it can be used any time that the required response is so complex that it may cause writing (and scoring) problems. If one wanted to know whether the candidate had grasped the main idea(s) of the following paragraph, for instance (Hughes 2002:148). As Hughes stated that Gap filling can be used to test the ability to recognise detail presented in support a main idea.

\section{METHOD}

The researcher uses descriptive qualitative as a research design. It is designed to analyze derivational affixes found in UNAS at senior high school. The process of this research involves collecting and gathering the data, then analyzing the data. In analyzing the data, the research uses content analysis method to analyze the data which are taken from gap fill paragraph on UNAS. According to Mile \& Huberman (1994:1) qualitative data usually in the form of words rather than number, have always been the staple of some fields in the social sciences, notably, anthropology, history, and political science.

The research variable in this study is analysis of derivational affixes in gap fill paragraph on UNAS at senior high school. The researcher will discuss about what kind of derivtional affixes found in gap fill paragraph on UNAS at senior hihg school, and also To help XII grade students to answer gap fill excercise.

The researcher analyze the derivatinal affixes there are in some gap fill paragraph found on UNAS. Derivarinal Affixes is change the word class of the word to which they are added. Affix to an already existing word to create a new word to help describe its use in a sentence, In order to improve student vocabulary.

The data found in gap fill paragraph on UNAS at senior high school. There are three questions about gap fill on UNAS but the researcher choose some years of UNAS to analysis that are UNAS 2012, UNAS 2013, UNAS 2014, UNAS 2015, UNAS 2016, because in every year there are three questions about gap fill. In this study the researcher chose five years to analyze, because the paragraph contained derivation affixes is only in the year was mentioned above. That we know the purpose of this research is to know the kind of derivational affixes there are in gap fill paragraph on UNAS.

In this study the researcher is as key instrument. It means the researcher himself is the primary data collection tool for gethering and analyzing of the data. The data will be describe qualitative in the form of derivational.

\section{Data Analysis Method}

Data analysis is a systematic process of search and preparation of the results the accumulated data collection, to understand, and what has been found to be at present. Data analysis includes work with data, data collection, organizing existing data, process data, and researching 
for new patterns and discover what's important and what we learn. Moreover, according to Miles and Huberman (1994), "Qualitative data analyses are divided into three concurrent flows of activity:

1.

3.
Data Reductions

Data reductions refer to the process of selecting, focusing, sampling, abstracting, and transforming.

2. Data Display

Data display is flow of analysis activity. It organized compressed assembly of information that permits conclusion drawing and action.

Verification

Conclusion drawing and verification is divided what things mean is noting regularities, patterns, explanations, casual flows, and preposition.

\section{DISCUSSION}

From the data finding of the research, there are derivational affixes and roots that can be found in gap fill paragraph on UN 2011/2012- 2015/2016. Here is the word of changing the part of speech that found in gap fill paragraph on UN 2011/2012 2015/2016:

1. Adverb

An adverb is normally made by adding the suffix $-l y$ to the adjective. The number of derivational affixes that adding suffix -ly have been found in gap fill paragraph on UN (national exam), are

- Recent (adjective) - recently (adverb)

- Actual (adjective) - actually (adverb)

- Alarming (adjective) - alarmingly (adverb)

- Angry (adjective) - angrily (adverb)

- Rapid (adjective) - rapidly (adverb)

- Sudden (adjective) - suddenly
- (adverb)

- Final (adjective) - finally (adverb)

- Harmonious (adjective) harmoniously (adjective)

2. Adjective

An adjective can be made find by adding - un to the noun or by adding-ive,-ing, -ed, -able, -less to the verb. In the gap fill paragraph on $\mathrm{UN}$, the researcher find derivational prefix $-u n$ :

- Like (noun) - unlike (adjective)

- Harmony (noun) harmoniously

3. Verb

A verb can be made by adding dis- to the adjective or by adding $e n$ to the adjective or by adding ento the noun. In the gap fill paragraph on UN, the researcher find derivational prefix - dis :

- Like (verb) - disliked (verb)

4. Noun

A noun can be made by adding ist or -ism to the noun or by adding -ion, -ment, -er to the verb or by adding adding -ness, -ity to the adjective. In the gap fill paragraph on UN (National Examination) only two derivational suffix that adding -ion and -ment. They are:

- Port (adjective) - portion (noun)

- Appoint (Verb) - appointment (noun)

The researcher have prediction to next UN (National Examination), the derivational affixes in gap fill paragraph on UN (National Examination) most frequently appear are suffix $-l y$ as an adverb marker.

\section{CONCLUSION}

The conclusion of this research can briefly described as following: the result of the research explained into two part, consisting common derivational affixes found in gap fill paragraph on UN 
(national Examination) and frequency derivational affixes found in gap fill paragraph on UN (National Examination).

Based on the findings of the research in chapter IV, the researcher can conclude several conclusions. Derivational affixes in gap fill paragraph on UN (National Examination) are -ly (8), un- (1), -ion (1), -ment (1), dis- (1). It shows that have the most frequently appear in gap fill paragraph on UN (National Examination) are suffix $-l y$ as an adverb marker.

The researcher concluded that the most found derivational affixes in gap fill paragraph on UN 2011/2012 - 2015/2016. Derivational suffix $-l y \quad(66,6 \%)$, derivational preffix $-u n \quad(8,3 \%)$, derivational suffix -ion $(8,3 \%)$, derivational suffix -ment $(8,3 \%)$, and derivational preffix dis- $(8,3 \%)$. The word of changing the part of speech that found in gap fill paragraph on UN (National Examination) are : adjective, adverb, noun and verb.

\section{REFERENCES}

Hughes, Arthur. 2002. Testing for Language Teachers (second edition). Cambridge University Press.
Lieber, Rochelle. 2009. Introducing Morphology. English Department University of new Hampshire. Cambridge University Press.

Miles, B. Metthew and Hubarman. A. Michael. 1994. Qualitative Data Analysis (second edition). Sage Publication: London New Delhi

Plag, Ingo. 2002. Word-Formation in English. Universitas Siegen: Cambridge University Press.

Thornbury, Scott. 2002. How to Teach Vocabulary. Endinburgh Gate: England. Publisher by: Bluestone Press, Charbury, Oxford Shire,

UK

Varatharajoo, Asmawi et.al. 2015. The Awareness of Morphemic Knowledge for Young Adults'

Vocabulary Learning. The Malaysian online Journal of Educational Science. 3(2), 45-56.

https://news.detik.com/wawancara/345640 1/mendikbud-sekarang-usbnpenentu-kelulusan-un-malah-tidak 06 September 2017 